\title{
Dinamika Sosial Ekonomi Penambang Pasir Tradisional di Desa Mataraman (1960-2010)
}

\author{
Norhidayat ${ }^{1}$, Rochgiyanti ${ }^{2}$, Rusdi Effendi ${ }^{3}$ \\ ${ }^{1}$ Mahasiswa Program Studi Pendidikan Sejarah Universitas Lambung Mangkurat \\ 2Dosen Program Studi Pendidikan Sejarah Universitas Lambung Mangkurat \\ ${ }^{3}$ Dosen Program Studi Pendidikan Sejarah Universitas Lambung Mangkurat \\ 1noorhidayat93@gmail.com, 2yantibjm87@gmail.com, 3effendi.rusdi@rocketmail.com
}

\begin{abstract}
This research oriented at the traditional mining sand in the village of Mataraman that is the business sector labor-intensive and has long lasting. The purpose of this research is to know about the lives of the miners traditional sand in the village of Mataraman sub-district Banjar Regency. The worst of conditions happened in the past years 1995 to 2000, while the best conditions during this time is the condition post monetary crisis over five years is 2000 and 2005. Sand mining in the village Mataraman also provides role for the economy villagers Mataraman, provide jobs, and becomes a magnet the economic activities and expand their villages indirectly also bring economic impact to its villagers.
\end{abstract}

Keywords: dynamic, sand miners, traditional.

\begin{abstract}
ABSTRAK
Penelitian ini berorientasi pada pertambangan tradisional pasir di Desa Mataraman yang merupakan sektor bisnis padat karya dan tahan lama. Tujuan dari penelitian ini adalah untuk mengetahui tentang kehidupan pasir penambang tradisional di Desa Mataraman Kabupaten Banjar. Kondisi terburuk yang terjadi adalah pada tahun 1995-2000, sementara kondisi terbaik selama waktu krisis moneter selama lima tahun, yaitu 2000 dan 2005. Penambangan pasir di Desa Mataraman juga menyediakan peran ekonomi desa Mataraman, menyediakan pekerjaan, dan menjadi magnet kegiatan ekonomi dan memperluas desa mereka, serta secara tidak langsung juga membawa dampak ekonomi bagi masyarakat.
\end{abstract}

Kata kunci: dinamika, penambang pasir, tradisional.

\section{PENDAHULUAN}

Sejak manusia dilahirkan sudah memiliki kebutuhan hidup. baik berupa kebutuhan jasmani maupun kebutuhan rohani. Usaha-usaha yang dilakukan manusia dalam memenuhi kebutuhan hidupnya bertitik tolak pada faktor esensial dari manusia itu sendiri, yaitu adanya dorongan alamiah untuk mempertahankan diri dan mengembangkan diri. Hal tersebut dilakukan dengan cara beragam, baik melalui sektor formal maupun nonformal.

Inilah yang menjadi alasan manusia untuk secara aktif melakukan kegiatan perekonomian. Kegiatan ekonomi dalam pengertian ini adalah berbagai usaha yang dilakukan manusia dalam memenuhi berbagai kebutuhannya baik sandang, pangan, papan, maupun kebutuhan-kebutuhan immateril. Agar 
dapat memenuhi kebutuhan tersebut manusia dituntut untuk bekerja, baik pekerjaan yang diusahakan sendiri maupun bekerja pada orang lain (Asikin, 1993 : 1). Apabila dilihat dari segi pekerjaannya, manusia memenuhi kebutuhan hidup dengan cara beragam baik melalui usaha dalam sektor formal maupun non-formal.

Dalam kajian sejarah kita dapat mengetahui bahwa aktivitas manusia dalam upaya memenuhi kebutuhan hidup adalah penggerak yang menjadikan sejarah pada suatu daerah memiliki kekhasan bila dibanding dengan daerah lainnya. Meskipun pada awalnya studi sejarah perekonomian Indonesia masih kurang berkembang dibanding dengan studi sejarah perekonomian beberapa negara lain di kawasan Asia. Namun, dalam kurun waktu kekinian studi sejarah Indonesia juga diwarnai studi sejarah bidangbidang non-formal, seperti petani, penambang dan sektor non-formal lain (Booth, 1988 : X).

Secara umum sektor non-formal adalah lingkungan usaha tidak resmi, karena lapangan pekerjaan diciptakan dan diusahakan sendiri oleh pencari kerja seperti wiraswasta. Usaha yang paling menguntungkan dari sektor non formal adalah membuka rumah makan di tempat-tempat yang ramai, membangun usaha pertambangan pasir tradisional, serta unit usaha kecil yang melakukan kegiatan produksi atau distribusi barang dan jasa untuk menciptakan lapangan kerja dan memberikan penghasilan. Mereka yang terlibat dalam unit kegiatan tersebut bekerja dengan berbagai keterbatasan, baik modal, fisik, tenaga, maupun keahlian.

Masyarakat yang bermukim di bantaran Kali Code dan Lereng Merapi memanfaatkan pasir hasil dari erupsi Gunung Merapi sebagai mata pencaharian mereka. Para pembeli yang memerlukan pasir turun langsung ke bantaran sungai. Berbeda dengan penjualan di luar Pulau Jawa, dimana pasir harus melewati beberapa tangan dulu. Terkait teknik penambangan, penambang pasir di daerah ini biasanya tidak menggunakan prosedur baku. Penambangan pasir yang dilakukan di kawasan lereng Merapi ini, selain membahayakan keselamatan para penambang, juga berpotensi merusak ekosistem.

Keberadaan pertambangan pasir ini mempunyai banyak peranan penting bagi masyarakat sekitar. Secara tidak langsung dapat mempengaruhi kehidupan ekonomi dan sosial masyarakat. Dalam bidang ekonomi, pertambangan tersebut dapat menambah penghasilan bagi para penambangnya, terutama dalam meningkatkan taraf hidup. Dalam bidang sosial, mereka 
dapat menjadikan pertambangan tersebut sebagai tempat terkumpul dan berinteraksi antar sesama penambang, bahkan pembeli.

Pada kenyataanya, sektor non formal memang banyak memberikan kontribusi bagi perbaikan ekonomi banyak warga masyarakat. Saat masa-masa krisis, sektor inilah yang relatif bisa bertahan terhadap kebangkrutan. Keadaan ini sangat membantu para penambang pasir untuk mempertahankan kemampuan memenuhi berbagai kebutuhan (Zanden dan Mark, 2012 : 10). Pasir sebagai material pokok dalam pembangunan fisik mempunyai fungsi yang sangat penting. Sehubungan dengan hal tersebut, pertambangan pasir memegang peranan yang sangat penting.

Meskipun peranannya sangat penting dalam pembangunan fisik di kota maupun desa. Namun, profil mereka jarang mendapat perhatian dari pihakpihak terkait. Selain itu, pada era sekarang banyak pembangunan fisik dilakukan, baik berupa pusat perbelanjaan maupun perumahan. Dalam kenyataannya, sebagai upaya modernisasi pembangunan menjadi sebuah kemutlakkan untuk dilakukan (Fakih, 2011). Namun, hasil pembangunan tersebut kurang dapat dinikmati oleh para penambang, sebab mereka hanya fokus pada pekerjaan sebagai penambang pasir serta minimnya upah dari hasil pekerjaan mereka.

Hal tersebut terjadi juga di Desa Mataraman Kecamatan Mataraman Kabupaten Banjar. Secara geografis, Desa Mataraman berada di Jalan Ahmad Yani yang menghubungkan antara Kabupaten Banjar dengan Kabupaten Tapin. Dilihat dari letaknya yang strategis, maka tidak mengherankan usaha ini selalu ramai pembelinya. Pembeli tidak hanya masyarakat sekitar Kecamatan Mataraman saja, banyak juga pembeli yang berasal dari luar kota seperti Banjarmasin, Rantau, Pelaihari, Kandangan bahkan Batulicin. Menyadari pentingnya hal tersebut, maka menarik untuk ditelusuri lebih jauh lagi tentang dinamika sosial ekonomi penambang pasir tradisional di Desa Mataraman dalam himpitan modernisasi.

\section{METODE}

Metode yang digunakan dalam tulisan ini adalah metode sejarah yang meliputi empat tahapan, yaitu heuristik, kritik, interpretasi, dan historiografi. Pada tahapan pertama, dalam sejarah dikenal dengan istilah heuristik yaitu tahapan untuk mengumpulkan data. Tahapan ini dilakukan dengan cara wawancara yang mendalam dengan para pelaku penambang pasir di Desa Mataramam. pengumpulan data juga dilakukan dengan studi pustaka yaitu 
mengumpulkan data-data berupa buku, jurnal, tesis, dan disertasi yang ada kaitannya dengan tulisan ini. Selain itu, pengumpulan data juga dilakukan dengan dokumentasi. Setelah tahapan mengumpulkan data, dilanjutkan dengan tahapan kedua yaitu kritik sumber untuk memverifikasi data-data yang telah dikumpulkan. Data-data yang telah dikumpulkan selanjutkan diinterpretasi agar data yang telah dikumpulkan dan diverifikasi dapat dijelaskan dan dapat memberikan makna dari setiap data tersebut. Tahapan terakhir yaitu historiografi yaitu menerjemahkan data dalam bentuk penulisan sejarah.

\section{HASIL DAN PEMBAHASAN}

Selama Orde Baru menjalankan pemerintahannya banyak sekali hasil yang bisa dirasakan terutama pembangunan fisik infrastruktur seperti listrik, jalan, jembatan, irigasi dan sebagainya. Namun, di balik keberhasilan Orde Baru ternyata menyisakan permasalahan yang pelik yaitu kesenjangan dan pengangguran. Kesenjangan tersebut terjadi pada banyak persoalan diantaranya; kesenjangan antargolongan ditandai dengan ketimpangan penguasaan akses terhadap sumber-sumber ekonomi. Kesenjangan selanjutnya terjadi antar sektor pembangunan. Selain itu, terjadi pula kesenjangan antar daerah (Nugroho dan Dahuri, 2012: xxi-xxii).

Salah satu bentuk kesenjangan tersebut yaitu dapat kita lihat dalam kehidupan ekonomi masyarakat, para penambang pasir di Mataraman. Kemajuan pembangunan yang terjadi sejak dekade 80-an, dalam kenyataannya tidak membawa banyak implikasi terhadap perekonomian para penambang pasir di Mataraman.

Upah buruh selalu mengalami kenaikan tetapi tidak banyak membawa pengaruh yang besar karena upah tersebut masih jauh dari cukup akibat kebutuhan hidup semakin tinggi. Untuk memenuhi kebutuhan tersebut, maka kebanyakan buruh mencari pekerjaan tambahan di sore hari setelah mereka kerja dari tambang pasir. Kebanyakan dari mereka ada yang bertani, berkebun, bahkan ada yang bekerja sampai malam menjadi buruh bangunan. Kondisi ini menunjukkan adanya ketimpangan pertumbuhan nominal dengan kecukupan minimal. Artinya, meskipun secara nominal terjadi peningkatan besaran upah, tetapi belum mampu memenuhi kebutuhan hidup minimal.

Berbagai ketimpangan yang terjadi adalah bentuk divestasi pembangunan, tidak pernah dihitung sebagai pengeluaran pembangunan yang digunakan selama pemerintahan Indonesia menjalankan roda 
pembangunannya (Chaniago, 2012: 12). Secara teoritis pembangunan idealnya mampu menjawab ketimpangan dalam masyarakat dan meningkatkan kesejahteraan secara bertahap.

Analisa ekonomi pada tingkat propinsi memang lebih mampu menonjolkan masalah-masalah riil yang dihadapi masyarakat setempat. Masalah kecukupan pangan, kondisi transportasi dan komunikasi, serta kemiskinan penduduk di daerah-daerah terpencil. Bahkan bisa juga dilihat secara nyata seperti masalah-masalah yang dihadapi dalam pertumbuhan dan pemerataan, pengangguran, dan keadilan sosial (Mubyarto, 1988: 223). Pengembangan ekonomi rakyat tidak dapat dicapai hanya dengan mengandalkan strategi pertumbuhan. Telah terbukti bahwa dampak kebijakan yang hanya mengandalkan pertumbuhan, justru semakin memperlebar jurang kesenjangan (Sumodiningrat, 2011: 6).

Secara umum tempat tinggal mereka, tidak ada fasilitas-fasilitas yang menunjang kehidupan. Kebutuhan hidupnya saja sudah pas-pasan apalagi harus memikirkan renovasi rumah atau menambah alat-alat elektronik. Pendapatan mereka yang rendah kebanyakan berdampak pada pendidikan anak-anak penambang. Banyak anak dari penambang pasir hanya lulusan Sekolah Dasar bahkan tidak sekolah. Kebanyakan anak mereka ikut membantu perekonomian orang tua seperti mencari batubara, untuk di jual kepada pengepul. Anak-anak penambang juga ikut menjadi buruh isi dan tani di kebun membantu orang tua.

Anak bagi sebagian besar masyarakat kelas bawah seperti penambang pasir di Mataraman adalah unit ekonomi. Keterbatasan penghasilan menyebabkan sebagian besar dari penambang pasir di Mataraman tidak mampu memberikan pendidikan sampai ke jenjang pendidikan tinggi. Sebaliknya anak-anak yang dinilai telah mampu bekerja diminta untuk membantu perekonomian keluarga dengan melakukan pekerjaan-pekerjaan ringan.

Dalam analisis pembangunan ekonomi, gambaran penting yang perlu diperoleh mengenai keadaan distribusi pendapatan adalah ciri-ciri keterkaitan antara pembangunan ekonomi dan corak perubahan distribusi pendapatan (Sukirno, 2010: 65). Secara garis besar distribusi pendapatan dari tahun ke tahun mengalami perkembangan, akan tetapi perubahan distribusi tersebut tidak selalu berkorelasi positif terhadap pemenuhan kebutuhan hidup buruh penambang pasir di Mataraman.

Guna memberikan gambaran yang komprehensif terhadap pendapatan para penambang pasir, data perbandingan penghasilan penambang dengan 
perbandingan UMR dari tahun 19802010 disajikan dalam Tabel 1.

Dalam data tersebut dijelaskan bahwa selama kurun waktu 1980-2010 upah buruh rata-rata berada dibawah UMR. Peraturan perundangan menjelaskan pengupahan karyawan dibawah UMR dengan alasan tidak memiliki status sebagai CV ataupun PT. Hal tersebut bukan merupakan suatu alasan atau pelepasan kewajiban bagi Pengusaha untuk dapat memberikan upah dibawah minimum yang ditetapkan oleh peraturan perundang-undangan.

Tabel 1

Perbandingan Penghasilan Penambang dengan Perbandingan UMR Tahun 1980-2010

\begin{tabular}{|c|c|c|c|c|}
\hline No & Tahun/Periode & UMR & Kenaikan & Penghasilan Rata-rata \\
\hline 1 & 1980-an & $\begin{array}{ll}\mathrm{Rp} & 18.000 \\
\end{array}$ & $?$ & $\begin{array}{ll}\mathrm{Rp} & 7.900 \\
\end{array}$ \\
\hline 2 & 1991 & $\begin{array}{ll}\mathrm{Rp} & 18.200\end{array}$ & $?$ & \multirow{4}{*}{$\begin{array}{ll}\text { Rp } & 17.500 \\
& \text { s/d } \\
\text { Rp } & 20.000\end{array}$} \\
\hline 3 & 1992 & $\begin{array}{ll}\mathrm{Rp} & 20.330 \\
\end{array}$ & $11.7 \%$ & \\
\hline 4 & 1993 & $\begin{array}{ll}\mathrm{Rp} & 23.930 \\
\end{array}$ & $17.7 \%$ & \\
\hline 5 & 1994 & 31.290 & $30.8 \%$ & \\
\hline 6 & 1995 & $\begin{array}{ll}\mathrm{Rp} & 36.820 \\
\end{array}$ & $17.7 \%$ & \multirow{5}{*}{$\begin{array}{ll}\text { Rp } & 30.000 \\
& \text { s/d } \\
\text { Rp } & 45.000\end{array}$} \\
\hline 7 & 1996 & $\begin{array}{ll}\mathrm{Rp} & 40.740\end{array}$ & $10.6 \%$ & \\
\hline 8 & 1997 & Rp 135.353 & $232.2 \%$ & \\
\hline 9 & 1998 & $\begin{array}{cc}\mathrm{Rp} & 153.971\end{array}$ & $13.8 \%$ & \\
\hline 10 & 1999 & $\begin{array}{ll}\mathrm{Rp} & 179.528 \\
\end{array}$ & $16.6 \%$ & \\
\hline 11 & 2000 & $\begin{array}{ll}\mathrm{Rp} & 213.700\end{array}$ & $19.0 \%$ & \multirow{5}{*}{$\begin{array}{c}\text { Rp } 250.000 \\
\text { s/d } \\
\text { Rp } 450.000\end{array}$} \\
\hline 12 & 2001 & $\begin{array}{ll}\mathrm{Rp} & 286.100 \\
\end{array}$ & $33.9 \%$ & \\
\hline 13 & 2002 & Rp 362.700 & $26.8 \%$ & \\
\hline 14 & 2003 & $\begin{array}{ll}\mathrm{Rp} & 414.500\end{array}$ & $14.3 \%$ & \\
\hline 15 & 2004 & $\begin{array}{ll}\mathrm{Rp} & 482.212\end{array}$ & $10.09 \%$ & \\
\hline 16 & 2005 & $\begin{array}{ll}\mathrm{Rp} & 536.300 \\
\end{array}$ & $11.22 \%$ & \multirow{6}{*}{$\begin{array}{c}\text { Rp } 450.000 \\
\text { s/d } \\
\text { Rp } 750.000\end{array}$} \\
\hline 17 & 2006 & Rp 698.959 & $23.27 \%$ & \\
\hline 18 & 2007 & $\begin{array}{ll}\mathrm{Rp} & 745.000 \\
\end{array}$ & $6.18 \%$ & \\
\hline 19 & 2008 & $\begin{array}{ll}\mathrm{Rp} & 825.000\end{array}$ & $10.74 \%$ & \\
\hline 20 & 2009 & $\begin{array}{ll}\mathrm{Rp} & 930.000\end{array}$ & $11.29 \%$ & \\
\hline 21 & 2010 & Rp 1.126.000 & $17.40 \%$ & \\
\hline
\end{tabular}

Amanat Pasal 90 ayat 1 UU No. 13/2003 menyatakan bahwa pengusaha dilarang membayar lebih rendah dari ketentuan upah minimum yang telah ditetapkan pemerintah setempat. Apabila pengusaha dalam memberikan kesepakatan upah kepada pekerja/buruh lebih rendah atau bertentangan dengan Undang-Undang, maka kesepakatan tersebut batal demi hukum. Dan pengusaha wajib membayar upah pekerja/buruh menurut peraturan perundang-undangan yang berlaku. Hal ini ditegaskan pada Pasal 91 ayat (2) UU No. 13/2003. Namun, pengaturan tentang pengupahan. Memberikan keringanan bagi pengusaha yang tidak mampu membayar upah sesuai dengan penetapan pemerintah setempat mengenai upah minimum. Pengusaha 
dapat meminta penangguhan untuk membayar pekerja/buruhnya dibawah upah minimum dengan cara meminta permohonan penangguhan yang lebih lanjut diatur dalam Kepmenakertrans No. 231/2003.

Perkembangan awal pertambangan pasir di Mataraman dalam dekade 80-an merupakan dekade yang kurang menggembirakan bagi penambang pasir. Penghasilan mereka yang jauh dari UMR, yaitu kurang dari 50\% UMR. Kondisi ini tentu saja jauh berada di bawah Kriteria Hidup Layak, sebagai dasar penetapan UMR. Dengan demikian, kondisi ini menjelaskan bahwa penghasilan yang mereka terima sangat jauh dari cukup untuk hidup sehari-hari.

Perkembangan yang cukup menggembirakan terlihat pada awal 1990-an. Penghasilan rata-rata penambang pasir hampir mencapai standar UMR. Meskipun belum juga sesuai UMR, tetapi sudah mencapai angka di atas $80 \%$. Pertambangan pasir Mataraman sebagai usaha sektor non formal tidak terlalu banyak terkena imbas dari pertumbuhan ekonomi Indonesia yang tinggi akhir dekade 80-an dan awal 90-an. Meskipun pada saat itu, pertumbuhan ekonomi Indonesia mencapai 7,3 hingga 8,2 (Tambunan, 2004 :32) Namun, sektor non formal seperti pertambangan pasir di
Mataraman hanya mendapat imbas tidak langsung dari pertumbuhan yang terjadi.

Selama kurun waktu 1995 sampai dengan 1996, sebenarnya keadaan tidak banyak berubah bila dibandingkan dengan masa sebelumnya. Naiknya upah penambang masih juga belum mencapai standar upah minimum. Secara nominal terjadi kenaikan upah, akan tetapi bila dilihat dari Kriteria Hidup Layak (KHL) sebenarnya perbandingannya tidak banyak berubah. Kondisi ekstrim terjadi pada akhir dekade 90-an, terutama tahun 1997 ketika Indonesia menghadapi krisis moneter. Pada tahun ini meskipun UMR melonjak naik lebih dari 200\%, tetapi upah buruh tambang pasir tidak mengalami peningkatan signifikan. Kondisi ini diperparah dengan harga kebutuhan yang melambung tinggi pada masa krisis moneter. Kondisi perekonomian penambang pasir pada masa ini dapat dikatakan merupakan kondisi terburuk dalam kurun waktu 1980 sampai dengan 2010.

Perbaikan kondisi perekonomian nasional mulai menampakkan hasil, yang menggembirakan ketika berada dalam kurun waktu sampai 2010. Dalam kurun waktu tersebut rata-rata upah buruh tambang telah mencapai standar UMR. Meskipun demikian, perkembangan standar kehidupan dan berkembangnya media telah menyebabkan masyarakat termasuk para penambang pasir 
mengenal berbagai alat pemuas kebutuhan yang semakin canggih. Kondisi ini disadari atau tidak, telah menjadi tekanan psikologis tersendiri bagi para penambang. Contoh sederhana misalnya, banyak anak-anak penambang pasir yang mulai menuntut untuk dibelikan motor, handphone dan sebagainya. Kondisi ini tentu menjadi beban tersendiri bagi penambang pasir. Tuntutan kehidupan suka atau tidak suka terus berkembang sesuai dengan perkembangan zaman, sementara penghasilan yang mereka terima tidak mampu mencukupi semua kebutuhan tersebut.

Pada tahun 2002 perekonomian mulai mengindikasikan adanya proses pemulihan ekonomi. Kondisi ekonomi nasional stabil membaik selama 2003. Kondisi tersebut secara tidak langsung telah menguntungkan perekonomian penambang pasir di Mataraman. Kestabilan harga kebutuhan pokok yang semakin membaik dan meningkatnya pendapatan memberikan kontribusi positif terhadap perbaikan kehidupan buruh tambang pasir di Mataraman.

Kurun waktu terakhir yaitu 2005 sampai 2010. Meskipun secara nominal terjadi peningkatan besaran upah, tetapi upah tersebut kembali tidak mencukupi kebutuhan hidup dan berada dibawah rata-rata UMR. Bila dibandingkan dengan kurun waktu sebelumnya, terlihat bahwa kondisi perbaikan ekonomi penambang yang terjadi pada kurun waktu 2000 sampai dengan 2004 tidak berlanjut pada kurun waktu setelahnya.

Secara umum kondisi kehidupan ekonomi penambang pasir dalam kurun waktu 1980 sampai dengan 2010 menunjukkan adanya dinamika kehidupan ekonomi penambang. Kondisi terburuk terjadi pada kurun waktu tahun 1995 sampai dengan 1999, sedangkan kondisi terbaik adalah kondisi pasca krisis moneter dalam kurun waktu tahun 2000 sampai dengan 2004.

Selain indikator ekonomi, kondisi kesehatan dapat menjelaskan bagaimana kehidupan penambang pasir dalam kurun waktu 1980 sampai dengan 2010. Pola waktu kerja yang panjang yaitu lebih dari delapan jam dalam sehari dan lokasi bekerja yang tidak steril telah memunculkan berbagai penyakit. Kebanyakan penambang bekerja pagipagi sekali dan selesai siang atau sore hari. Pekerjaan mereka tidak lepas dari berendam dalam air. Hal ini banyak menimbulkan penyakit air seperti penyakit Kadas, Kurap, Kutu Air, Varises, dan Kapalan. Penyakit tersebut dialami penambang pasir Desa Mataraman tetapi tidak pernah diobati karena penghasilan yang pas-pasan.

Para penambang juga mengalami berbagai penyakit lain terutama penyakit dalam seperti penyakit Paru-paru, 
jantung, lambung, dan lain sebagainya. Kondisi kesehatan yang buruk pada penambang dan keluarganya merupakan beban tersendiri dalam kehidupan para penambang pasir di Mataraman.

Keterbatasan pengetahuan yang berpadu dengan keterbatasan ekonomi telah menyebabkan para penambang pasir di Mataraman tidak mampu untuk melakukan mobilitas sosial vertikal. Dalam kurun waktu 1980 sampai dengan 2010 terlihat bahwa kehidupan penambang pasir tidak mengalami perubahan yang signifikan. Perekonomian para penambang pasir di Mataraman sebagian besar terbatas pada pemenuhan kebutuhan sehari-hari dan masih belum mampu menyediakan sumberdaya untuk perbaikan hidup di masa yang akan datang.

Secara umum, kondisi tersebut terdapat kondisi kausalitas. Rendahnya penghasilan akan menyebabkan ketidakmampuan mereka dalam mengembangkan kehidupan. Selain itu, rendahnya penghasilan juga menyebabkan penambang pasir tidak mampu memperbaiki kondisi kehidupan, termasuk kondisi kesehatan. Keadaan tersebut diperparah dengan tidak adanya jaminan asuransi kesehatan pekerja bagi penambang pasir tradisional. Dampak jangka panjang yang sangat memprihatinkan adalah ketidakmampuan keluarga penambang pasir untuk mempersiapkan masa depan lebih baik bagi putra-putrinya. Kondisi ini bila terus terjadi akan menyebabkan terpeliharanya kemiskinan terstruktur dalam masyarakat. Artinya satu generasi akan mewariskan kemiskinan pada generasi selanjutnya.

\section{PENUTUP}

Penambangan pasir di Desa Mataraman Kecamatan Mataraman Kabupaten Banjar sudah ada sejak tahun 1980, keberadaannya banyak menarik perhatian masyarakat khususnya para laki-laki untuk dijadikah sebagai lahan pekerjaan. Pertambangan pasir dari tahun 1980 sampai 2010, banyak terjadi kesenjangan sosial khususnya bagi para penambang dan buruh.

Dinamika kehidupan para penambang pasir tradisional jauh dari kata layak, jangankan untuk menabung, makan sehari-hari saja masih kekurangan. Berbeda dengan pemilik tambang, mereka dapat menikmati hasil tersebut dengan menabung, membeli rumah dan alat elektronik lainnya. Tidak sesuai dengan kemajuan pembangunan dan menjamurnya tempat hiburan yang banyak menggunakan material pasir. Para penambang tidak dapat menikmati kemajuan karena tidak ada biaya. Upah yang rendah ditambah tidak ada pekerjaan tambahan membuat kehidupan penambang pasir tradisional 
semakin sulit. Apalagi dengan datangnya musim hujan, maka air sungai tempat menambang akan meluap bahkan berbulan-bulan.

\section{REFERENSI}

Asikin, Z, dkk. 1993. Dasar-Dasar Hukum Perburuhan. Jakarta : Rajawali Pers.

Booth, A., et. al. 1988. Sejarah Ekonomi Indonesia. Jakarta : LP3ES

Zanden, J. L. dan Mark, D. 2012. Ekonomi Indonesia 1800-2010. Jakarta: Kompas dan KITLV.

Fakih, M. 2011. Runtuhnya Teori Pembangunan dan Globalisasi. Jogjakarta: Insist Press dan Pustaka Pelajar.

Chaniago, A. A. 2012. Gagalnya Pembangunan, Membaca Ulang Keruntuhan Orde Baru. Jakarta: LP3ES.

Mubyarto. 1988. Sistem dan Moral Ekonomi Indonesia. Jakarta: LP3ES.

Sumodiningrat, G. 2011. Membangun Perekonomian Rakyat. Yogyakarta: Institute of Development and Economic Analisys bekerjasama dengan Pustaka Pelajar.

Sukirno, S. 2006. Ekonomi Pembangunan, Proses, Masalah, dan Dasar Kebijakan. Jakarta: Kencana Prenada Media Group.

Tambunan, T. 2004. Perekonomian Indonesia dan Peran Kadin Tahun 1994-2004. Jakatra: Yayasan Kadin.

Nogroho, I dan Dahuri, R. 2012. Pembangunan Wilayah, Perspektif Ekonomi, Sosial dan Lingkungan. Jakarta: LP3ES. 